Review paper

\title{
Medical physics and physics in medicine in Ireland (part 1: 1600- 2000)
}

\author{
Jim Malone ${ }^{\mathrm{a}, *}$, Barry McMahon ${ }^{\mathrm{b}}$ \\ ${ }^{a}$ School of Medicine, Trinity College Dublin, Ireland \\ ${ }^{\mathrm{b}}$ TAGG Research Centre, Trinity College Dublin, Ireland
}

A R T I C L E I N F O

\section{Keywords:}

History

Medical physics

Ireland

Imaging

Radiation

Radiotherapy

\begin{abstract}
A B S T R A C T
Medical physics and other contributions from physics to medicine are relatively well known, if not well documented in Ireland. Less well known are contributions from medicine to the development of physics, which can and do occur. This paper addresses examples of all three. The methods employed include documentary research and interviews with those who share(d) the stage in the area. Documentary evidence for historical aspects of medical physics over the last century are relatively sparse and incomplete. Notwithstanding this, they can and do enable a picture to be built up of how the arrangements in place now have come about, particularly when they are accompanied by mature recollections of the participants.

Good critically assessed and accessible sources have been identified covering the seventeenth to nineteenth century material presented. Examples are presented based on the work of significant contributors, each with strong Irish connections, including Robert Boyle, Erwin Schrödinger, Fearghus O'Foghludha, and Edith Stoney the first female medical physicist. Their contributions are striking and continue to be relevant now. The findings provide a rich context and heritage for medical physics in Ireland and in the international community. They will include the contemporary period in a second paper, Part 2 of this study.
\end{abstract}

\section{Introduction}

Medical physics and contributions physicists made to medicine have a long and interesting, if little studied history. In addition, there are direct contributions from medical practitioners to physics over the centuries. No comprehensive account of these interactions between medicine and physics in Ireland is available to date. This paper will address the period commencing with Robert Boyle during the Enlightenment in the 1600 s, to the late twentieth century. A further paper (Part 2) will look in more detail at the period from 1994/5 to the present day. The methods employed rely mainly on documentary research for the period up to the early twentieth century. Thereafter, it has been possible to supplement the documentary trail with the recall of those who shared the stage in the area. Both papers are presented in the context of a growing body of work on the history of medical physics and interactions of physics and medicine over the last generation with some extending back to the end of the nineteenth century $[1,2]$. However, the deeper heritage of physics-medicine interactions, with roots in the scientific revolution, is currently also attracting attention, and this paper starts from these [3].

The paper provides a historical narrative of the story of medical physics in Ireland in the twentieth century, mainly in Sections 5 and 6.
In addition, the authors identified individuals and institutions, with strong Irish connections, that played an important part in the developments (including John Joly, Erwin Schrödinger, Fearghus O'Foghludha, Edith Stoney the first female medical physicist, and St Luke's Hospital Dublin). This, including Part 2, is the first attempt at a narrative history of developments of physics in medicine and medical physics in Ireland, and it is hoped it will provide a rich context of heritage for future developments in the area.

\section{Materials and methods}

The methods employed include documentary research, interviews with those who share(d) the stage in the area, and preliminary survey results (Section 7). The findings from these sources are provided for the following periods:

- Section 3: The Enlightenment (17th/18th centuries).

- Section 4: Nineteenth and early twentieth centuries.

- Section 5: Twentieth century up to $\sim 1970$.

- Section 6: Twentieth century from 1970 to the mid-nineties/ end of century.

- Section 7: Some conclusions and introductory data for contemporary

\footnotetext{
* Corresponding author.

E-mail addresses: jifmal@gmail.com, jfmalone@tcd.ie (J. Malone), barry.mcmahon@tcd.ie (B. McMahon).
} 
period.

Excellent documentary historical sources for Irish contributions/ contributors from physics to medicine in Sections 3 and 4 have been identified. The authors have had an interest in the origins of physics in medicine in Ireland for many years and, based on historical research and space limitations, have chosen a limited number of prominent figures to present here. The more recent periods rely on a mixture of documentary sources and the memory of participants, which often carry the biases of the times and the individuals involved. They are also relatively sparse, and unsurprisingly, often lack mature contextual analysis.

Regarding referencing, to avoid excessive repetition, those references that apply generally to a section are placed at the end of the first appropriate paragraph in the section to which they have a relevance. Many of the references do not have a readily accessible on-line presence. To compensate for this, and provide access to additional source material, a popular on-line source is given (e.g. Wikipedia) if such exists and is balanced in terms of quality and coverage.

In June 2019 an on-line survey of contemporary medical physics in Ireland was undertaken. It was facilitated by the Irish Association of Physicists in Medicine (IAPM) electronic news group. An outline of its results are presented in Section 7, and it will be fully reported in Part 2.

\section{The enlightenment period (1600-1800)}

In this section, we present two important contributions to which medical physics is indebted. First, Robert Boyle, unfortunately known to many only for Boyle's Law, was an extraordinary polymath who contributed to both medicine and physics. Second, the first "textbook" on physics as we understand it today, had its origins in lecture notes which owe much to two Dublin physicians, Richard Helsham and Bryan Robinson.

\subsection{Physicist contributing to Medicine: Robert Boyle (1627-1691)}

Robert Boyle (1627-1691) is a compelling figure; he is sometimes known as the father of chemistry and the son of the Earl of Cork (Fig. 1). He was a polymath, contributing to many fields including chemistry, physics, medicine, alchemy, theology, and methodology of science. He was born and brought up around Lismore Castle (Ireland), later schooled at Eton, travelled widely in Europe, and eventually settled in Oxford and London. His "New Experiments Touching the Spring of Air and its Effects" demanded enormous leaps of imagination, proposing air is made up of corpuscles (anticipating the modern atom), had a "spring"; and that its behaviour could be accounted for by a mechanical model. King Charles II thought highly of him and told him that he "deserved a statue", but he refused all honours and offices, including Presidency of the Royal Society, a noble title, and a bishopric [4-7].

Boyle was cautious and guided by what he could observe. He felt science was blighted by premature systematization and elaborate theoretical formulations and was hostile to both. He, and Newton, insisted on empirical verification, which led to a radical reframing of what science was about. Many prominent figures took a poor view of experiment including Hobbes who launched an attack on Boyle and Christian Huygens, believed that "he (Boyle) wasted his talents trying to establish by experiment that which he (Huygens et al) knew to be true by the faculty of reason alone". However, Boyle's genius lay in his choice of method, which required of him the most rigorous approach to experiment and, further, he chose to put all he found into the public domain.

He contributed substantially to medicine, physics, and the life sciences [8]. He was deeply religious and lived an exemplary, if somewhat stoic Anglican life. Two examples are presented to indicate the breath and originality of his work related to medicine. First, a brief account of some work on respiration. This used a vacuum pump and sealed vessel

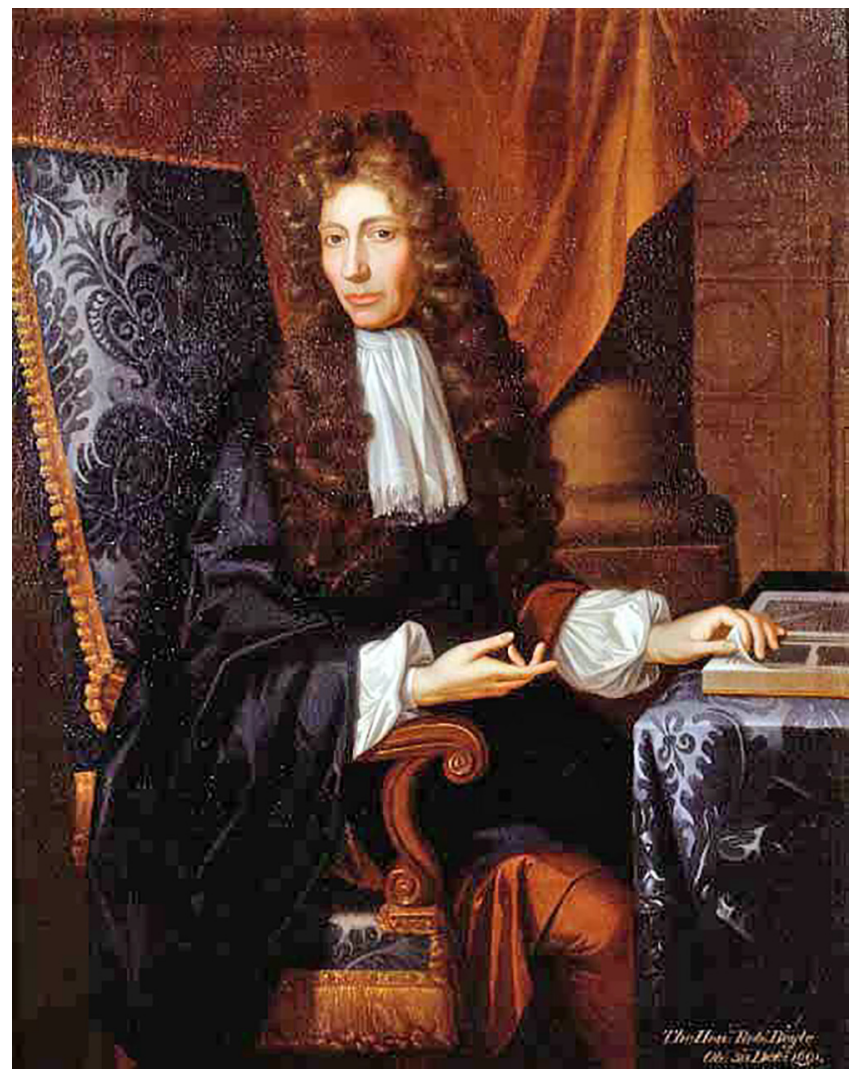

Fig. 1. Robert Boyle (1627-1691), portrait which hangs in the Royal Society in London.

to demonstrate that air was necessary for respiration in many species. From this, he went on to perform experiments that are even more telling. One involved demonstrating that a flame could not exist for long in a sealed flask or vacuum. He then demonstrated that there was a similarity between what sustained the flame and what sustained respiration and life, eventually using the term 'flama vitalis' or vital flame for whatever in the air sustained life. This work of Boyle was highly original; it took place long before the discovery of oxygen, and places him in the first rank of scientific achievers.

The second example is from his book on blood. His accounts of experiments are engaging: "Having Hydrostatically examin'd the Serum of Humane Blood, we found it heavier than common water. For a piece of Red Sealing Wax, being suspended in a good Balance by Horse hair, was found in the air to weigh $3 j+56 \mathrm{gr}$. And the Water $35 \mathrm{gr}$., but did in the Serum weigh but $33 \mathrm{gr}$ This Tryal was confirm'd by a more exact one, made with an instrument that I purposely caus'd to be made for weighing Liquors nicely, in which, when common water weighed 253 grains, an equal bulk of Serum weighed 302. And because I suppos'd that all Serums of Humane Blood would not be of equal Specific Gravity, I thought fit to try that the Blood of another person in the same instrument, and found it to weigh two grains less, that is 300 grains in all". He performed many similar investigations with other body fluids [9].

Boyle was awarded an MD by Oxford but pointed out he never practiced medicine, except on himself, "so that he would have less need of them that profess it". He collected an extensive range of the cures, and initially delayed their publication, concerned not to alienate physicians who jealously guarded this knowledge. Eventually he published them so that they would be broadly available. He reflected deeply on the practice of medicine, and the arrangements necessary to ensure it served patients well. He was critical of Galen's approach, still popular in his time. Galen was a second century physician, whose views on diagnosis and treatment of disease were being challenged. Boyle's case for a more scientific and effective alternative patient centred approach was 
powerful, and illustrates his capacity to grasp broad and difficult issues. A prominent Boyle scholar states he felt 'many of the treatments were harmful rather than beneficial and — in acute diseases, doctors were often inappropriately timid: in such cases, the physician might benefit from the caution but not the patient'. He initially committed these thoughts to paper around 1660 but their publication was delayed until much later, and some were not published until after he died in 1691. Instead he adopted a strategy of publishing work from science that could be put to effective use in medicine. This better suited his temperament [5].

Boyle's science is the rich harvest of an unusual direction taken by a scrupulous religious personality. Western Science has absorbed the culture he created, and lives by it, ironically like the air we breathe, without being conscious of it, its qualities, or its truth. The Chair of Medical Physics to which one of the authors was appointed by Trinity College Dublin was named to honour Robert Boyle and promote science as an integral part of national culture.

There are signs of some success, including the existence of an annual Robert Boyle Summer School. Another is an exhibition of paintings exploring colour by artist Nuala Clarke in Spring 2019. It was inspired by Boyles writing in which the artist delights. She says: - [His] work maps internal space — where colour and form are felt - and structure shifts until a rightness or truth is felt. - [He also says] "... even when we find not what we seek, we find something as well worth seeking as what we missed." And it is easy to agree with her, his texts are eccentric, but none the less illuminating and a great pleasure for a medical physicist to persue $[10,11]$.

\subsection{Medicine contributes to Physics: Helsham and Robinson's book}

Twenty first century medical physics is based on application of fundamental findings from physics to problems in medicine. However, modern physics also owes an unexpected debt to medicine and medical practitioners, many of whom contributed to its creation. What follows is an exceptional example involving two Irish Physicians, Richard Helsham, and Bryan Robinson; both worked in Dublin in the first half of the eighteenth century. They were contemporaries of Newton, shared the enlightenment and were advocates of what it had to offer. Their textbook, A Course of Lectures in Natural Philosophy, (Fig. 2) was centre stage for over a century, and shaped the physics we now know [12-14].

\subsubsection{Richard Helsham (c.1682-1738)}

Richard Helsham was born just outside Kilkenny in southeast Ireland, and took a BA at Trinity College Dublin, in 1702. By 1713, he had also been awarded degrees in medicine, including an MD and Fellowship of the nearby Royal College of Physicians in Ireland (RCPI). He was deeply committed to all things medical and scientific, and in 1716, he became President of the RCPI. When Trinity decided to include science courses in the University for the first time, he developed a series of lectures drawing on Newton's Natural Philosophy. Both Trinity and the RCPI medical students attended these. He gave the lectures for thirteen years without payment and was eventually rewarded by the College when he was appointed first Erasmus Smith's Professor of Natural and Experimental Philosophy. He was also appointed to the Chair of Physic. Note in Fig. 2, Helsham's designation as holder of both Chairs [15-17].

He was a well-known, well-regarded public figure, and a congenial man about town. He was retained by the city to advise on the design of the waterworks and received the Freedom of Dublin in return. The lectures include analysis of fluid flow over obstacles, through pipes and orifices, obviously the result of this work. He was friendly with the philosopher, George Berkley, and was physician to Jonathan Swift, the cantankerous writer of Gulliver's travels. Swift described him as 'an ingenious good-humour'd Physician, a fine gentleman, an excellent scholar, easy in his fortunes, kind to everybody.' He died relatively young in 1738.

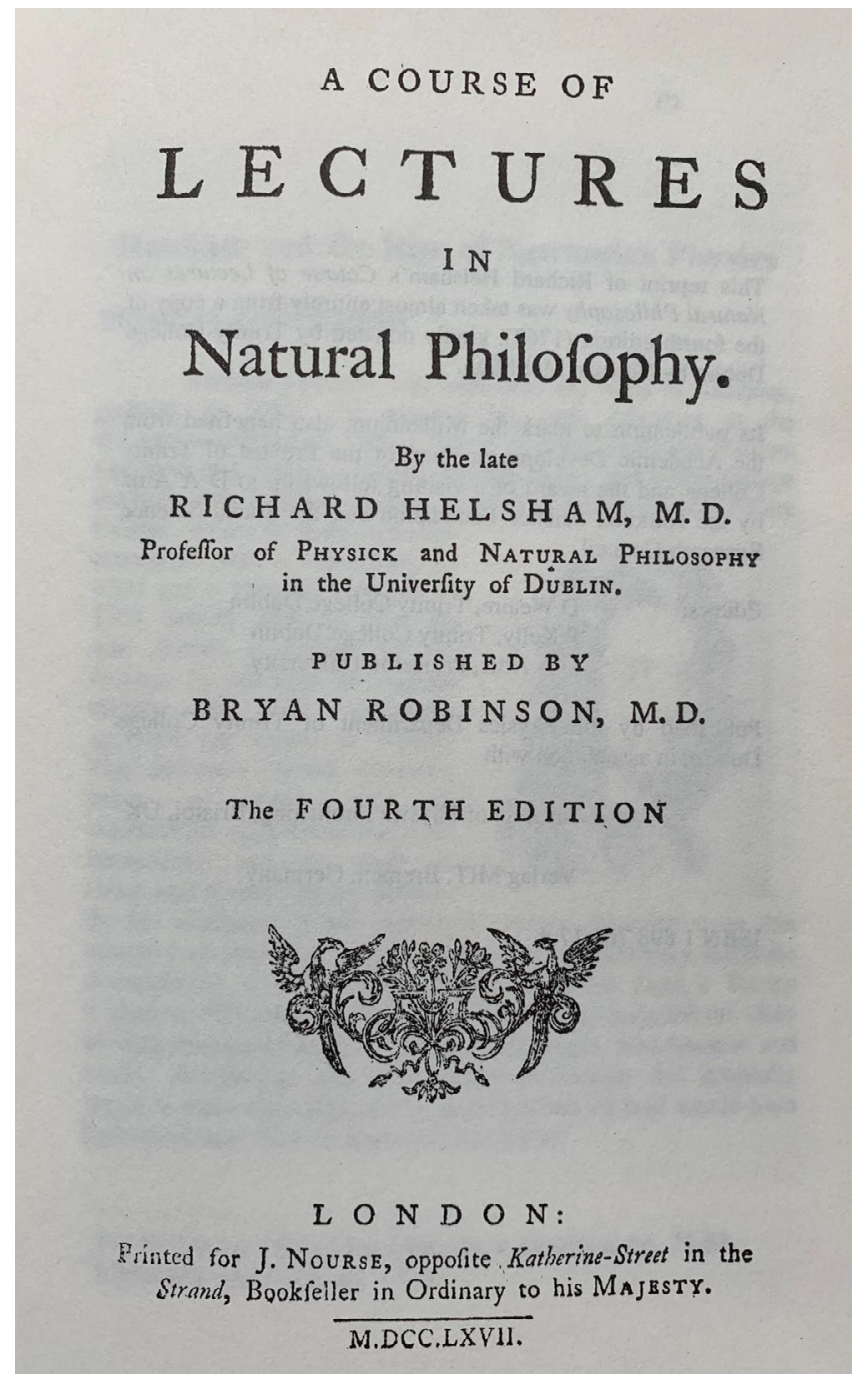

Fig. 2. Title cover of Helsham and Robinson's famous lecture series.

\subsubsection{Bryan Robinson (1680-1754)}

Bryan Robinson was born in Yorkshire and moved to Dublin where he graduated in medicine and received an M.D (1711). He was briefly anatomical lecturer in the new Trinity medical school (1716-17). In 1712 he was awarded Fellowship of RCPI and was later elected president. He was also appointed Regius Professor of Physic and is among the most able holders of that prestigious chair. A large portrait of him hung in the office of the Dean of the School of Medicine until recently when it was removed for conservation $[17,18]$.

Robinson almost perfectly complemented Helsham's pragmatic and practical approach. He created elaborate theories and devised more demanding treatments of physical and biological problems. Today, he is best known for two publications: his Treatise of the Animal Oeconomy (1732-3) and A Dissertation on the aether of Sir Isaac Newton (1743). Both demonstrate, Robinson's wish to extend Newton's approach, including mathematical treatments, into medicine. His interest in "the (a)ether" was wide ranging and he used it to help explain muscular motion, and a mechanical theory of animal bodies. Robinson set about publishing a book based on Helsham's lectures after the latter died.

\subsubsection{A course of lectures in Natural Philosophy}

Helsham and Robinson are known today for the book, A Course of Lectures in Natural Philosophy. Robinson added a preface to Helsham's lectures, - quoting Newton on methodology, and appendices which improved the derivation of some of Helsham's results. This was Dublin 
University Press's first scientific book, and it became a "best seller". The first edition appeared in 1739, and thereafter it went through eight editions, the final issued in 1834 (in Dublin, London and Philadelphia). It was a required text in Trinity until 1849, and the authors have noted it still being advertised for sale in 1868 .

In the second half of the 20th century Norman McMillan (Carlow IT) sought, without success, a copy of the book in the leading libraries in Ireland and UK. Eventually, he found a 1767 Fourth Edition in Green's (now defunct) Dublin bookshop, and generously donated it to the Physics Department in Trinity College. Denis Weaire, the then successor to Helsham in Erasmus Smith's Chair, produced a fine reprint version of this edition, which was published by Trinity College Physics Department in association with the Institute of Physics (London), as part of the year 2000 millennial celebrations. Copies are readily available from multiple online sources at modest prices [14].

Helsham's simple clear approach avoided the controversies and scientific disputes of the time and generally advocated the experimental method. He preferred to offer his readers a study of scientific investigation made 'entertaining and delightful'. The scope of physics in this influential book includes much we still see in today's syllabuses. However, it excludes heat (belonged to chemistry), and electricity/ magnetism/celestial dynamics are barely mentioned. John Roche, in a European Journal of Physics review wonders if today's physics undergraduates can relate the rather abstract mathematics they use to physical meaning [19]. He feels that selected readings from Helsham's book might help them recover the excitement of an "utterly clear" understanding of mathematical expressions of nature.

\section{The nineteenth century (1800- 1900)}

During this period, Irish medicine went through a "golden age", and several of the contributors to it used interesting physical associations. Space considerations only allow one example of these, Samuel Haughton, be included here. Others, for example members of the Stokes family are considered elsewhere $[12,13]$.

\subsection{Physics contributing to Medicine: Samuel Haughton (1821-1897)}

Samuel Haughton, like Boyle, was interested in everything in the natural world, a polymath who did much to bring physics into medicine (Fig. 3). He was born in Carlow to a Quaker family but was brought up in the Church of Ireland (Anglican) and entered Trinity College in 1838 where he studied mathematics and science. He excelled as a student, graduated at the top of his class in Mathematics, and was the youngest graduate ever to be elected to Fellowship. He died at age 76 in 1897 $[12,13,20]$.

He became aware that the chair of Geology was due to be filled. An awareness of the opportunities occurring around him was characteristic of his career. He was prepared to plan, even if it involved a long game. In this case, he was successful and appointed Professor, a position he filled with great distinction.

\subsubsection{Medical School reform and other activities}

Some years later, at age 37, Haughton was riding the crest of a wave. He was successful and had been elected to Fellowship of the Royal Society (FRS). But, in what seemed like an eccentric step backwards he entered the medical school as a student, and graduated in 1862 with MB and MD. Some say he was planning to reform the medical school and registering as a student was the first step on that road.

There is no doubt that the school left much to be desired with concerns about the curriculum, discipline among the professors, and a new act of Parliament on the education and training of doctors. Reforms were also required opening appointments, including Professorships, to all religious denominations. Previously Catholics, (among others) had been excluded. The new act also opened the Chairs of Surgery,

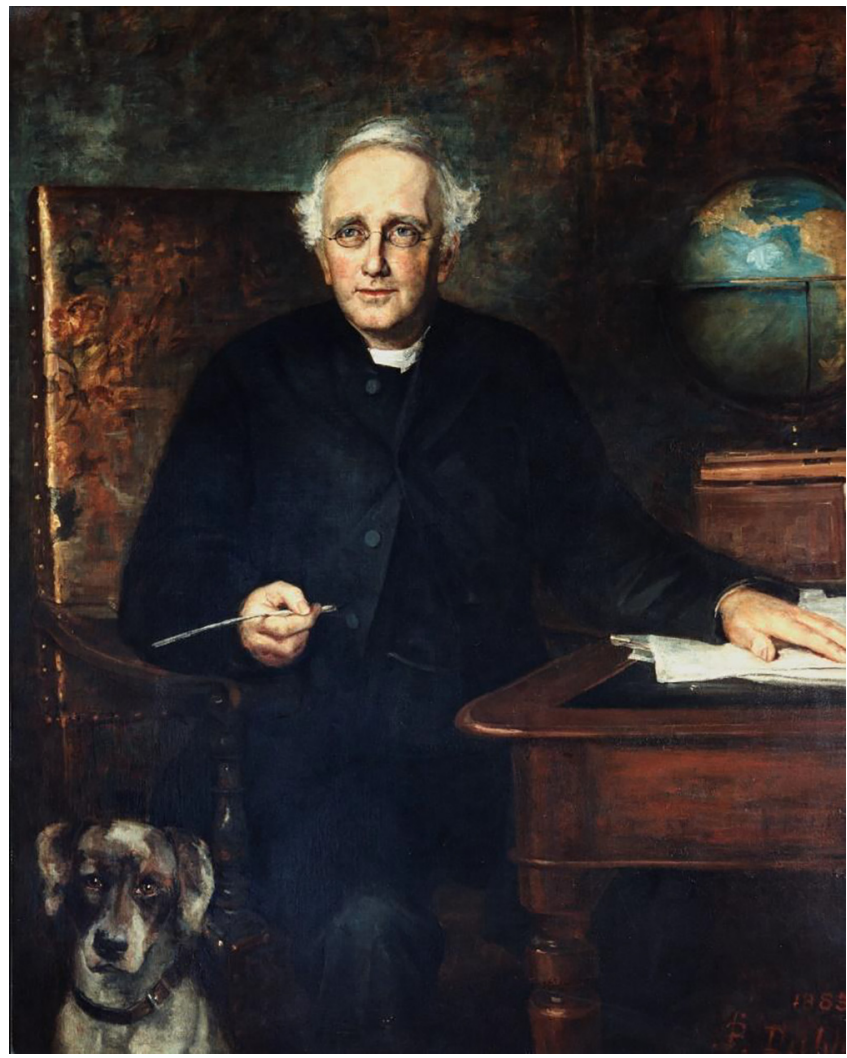

Fig. 3. Samuel Haughton (1821-1897), portrait from the Senior Common Room in Trinity College Dublin.

Chemistry, Anatomy and Botany to candidates without medical qualifications. By this time, Haughton had the ear of the College Board and was appointed registrar of the medical school. While this wasn't universally welcomed, all agree he was an outstanding administrator. He was probably the most influential person in the medical school from 1862 until the second half of the 1890's. He also devoted himself to other projects, particularly to creating functional teaching hospitals, particularly Sir Patrick Dunn's.

\subsubsection{Scientific career, animal mechanics, blood pressure and the long drop}

Haughton's contributions to Geology were considerable. He worked on tides and did exceptional work on the age on the earth. On evolution, Haughton came down on the wrong side, but based on a sound argument using energy considerations, in a Principle of Least Action.

For the purpose of this paper, it is his work on animal mechanics that we wish to recall. He published 30-40 papers on this topic, many of them substantial and using well-crafted mathematical treatments. His fascinating book, Animal Mechanics, is still available in facsimile form. It describes the form, structure, action, and energy considerations, for muscle and bone in a bewildering variety of species. It is a splendid book full of refreshing asides, giving some insight into Haughton's personality, and recalls Boyle's descriptions of observations and experiments [21].

For example, he did a lot of work on the heart, which required calculations of chamber volume, ejection fraction and blood pressure. Blood pressure could not be routinely measured at the time, and he was not convinced that the available work (Hale's) could validly be extrapolated from the horse to man. He eventually calculated blood pressure in man from the distance unrestricted arterial blood travelled through an operating theatre during surgery, and confirmed, to his own satisfaction, the value of blood pressure in humans in a plausible way.

One of Haughton's more bizarre, and yet humane, contributions relates to the mechanics of execution by hanging, using a long instead 
of a short drop. His paper, On Hanging considered from a Mechanical and Physiological point of view, was published in 1866 . He argued that humane hanging required a drop of sufficient length to break the person's neck. Otherwise, he argued, the person was strangled and suffered much. He subsequently participated in a commission on judicial hanging and succeeded in having a much more humane method adopted. There is much more in this endlessly fascinating book.

In terms of recognition, rising to high office, and using it well over a long period, Haughton achieved much. Like Boyle he also suffered somewhat in his science for not having a single focus for his work. Indeed, he published so much and so widely that Darwin at one point, probably out of frustration, asked: How many Haughton's there were in Dublin?

\section{The early twentieth century (1900- 1950)}

The late nineteenth and early twentieth centuries saw much excitement about radiation physics throughout the world and Ireland was no exception. On April 13th 1896, Brother Potamian O'Reilly undertook one of the first Irish X-rays in De La Salle College, Waterford. The radiograph demonstrated the presence of a steel splinter in the hand of a young woman. Around the same time, many others began to explore this exciting new field.

During this period, medical physics as we know it today began to emerge in Ireland. This happened very quickly, and John Joly's work (5.1) on radium treatment is recognisable as medical physics and is a forerunner on the road to modern brachytherapy. This continued in St Luke's hospital (5.4) once it was established in the middle of the century and the first salaried physicists were employed in the health service. Earlier Edith Stoney (5.2), a young woman of Irish extraction was appointed the first female medical physicist for first medical physicist in London. The era also had some surprising contributions from academic physics to medicine and we include one from Erwin Schrödinger (5.3), who had to flee Austria in the run up to WW2, lived in Dublin, and became an Irish citizen.

\subsection{Medical Physics: John Joly (1857-1933)}

Joly was born in County Offaly in Ireland (Fig. 4). His father, the local rector, was of Belgian origin, while his mother, a countess, had English, German, Italian and Greek connections. He graduated in Engineering at Trinity College in 1882 with first place and was simultaneously awarded a first-class degree in modern literature. He was elected to Fellowship of the Royal Society (FRS) in 1892 and awarded the Boyle Medal of the Royal Dublin Society (RDS) in 1911. He worked in Trinity's Engineering and Physics departments before being appointed to the Chair of Geology and Mineralogy in 1897, a position which he held until his death in 1933 in Dublin [22-24].

\subsubsection{Scientific work}

His scientific work covered an extraordinary range and included notable insights into fundamental aspects of nature and their application. In 1886 he proposed a theory on the slipperiness of ice. Like Haughton, he was intrigued by the question of the age of the earth and proposed a method for its calculation based on the accumulation of sodium in the oceans. He concluded it was $80-100$ million years old, challenging other results of the time. Later, this method was superseded, and based on radium and radioactive minerals he estimated that the beginning of the Devonian geological period could not be less than 400 million years ago, which is in line with modern calculations. He also developed an explanation of the upward movement of water in plants the cohesion-tension theory, which still holds sway today. Finally, he invented the first single plate colour photographic processes, and a number of optical and thermal instruments, some of which still bear his name [22,24].

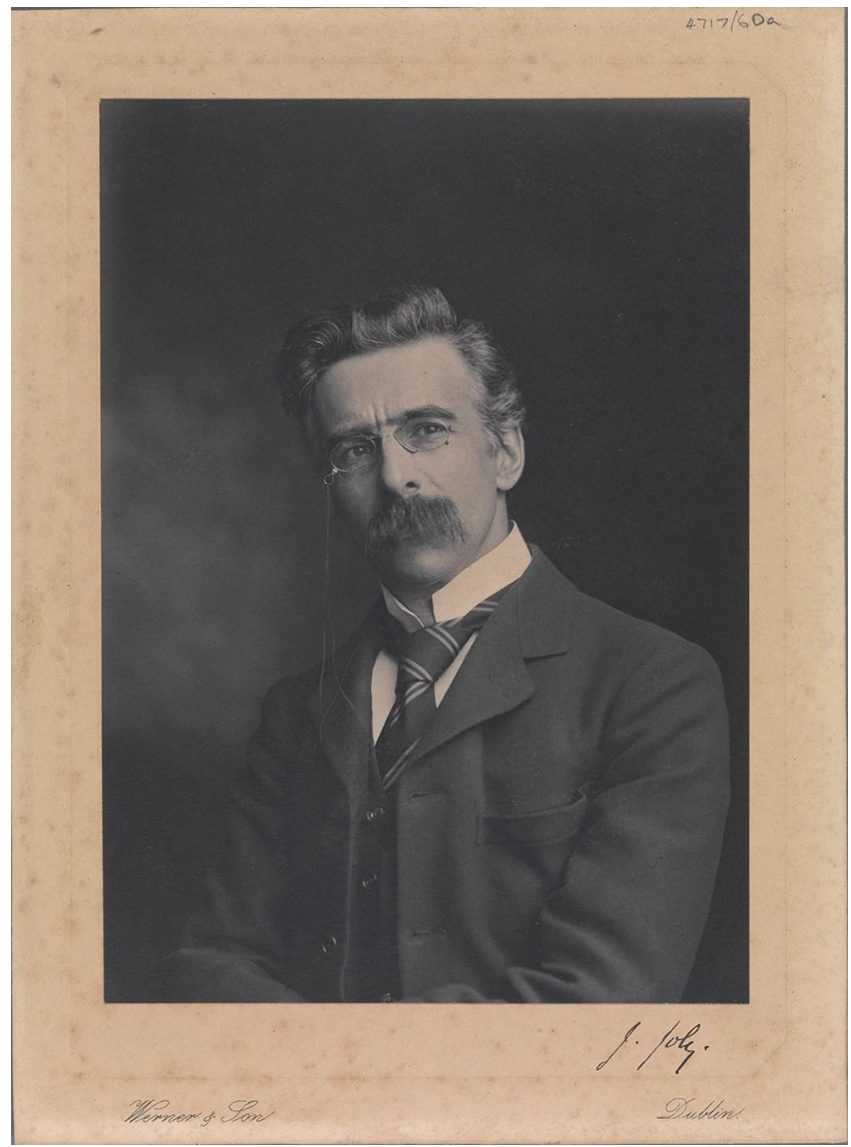

Fig. 4. Photo of John Joly (1857-1933).

\subsubsection{Joly, medical physics and the Dublin method}

More important, from the perspective of this paper, was his work on radium in collaboration with Walter Stevenson a Dublin radiologist/ surgeon/ cancer specialist. Although an engineer and geologist, John Joly's work in this area is recognisably Medical Physics. The earliest known clinical use of radiation therapy in Ireland followed a donation by Marie Curie of a radioactive sample to Joly. In the early 1900s Joly and Stevenson, collaborated at Dr Steeven's Hospital. Their early work was both dangerous and expensive, as it involved placing radium, sometimes as a single source, in tumours. Joly collected the radioactive gas given off by the radium, i.e. radon, and used it instead. This was a major improvement from the point of view of both safety and ongoing expense. The radium could be used repeatedly, and in due course a method was developed of incorporating the radon gas into hollow needles which were positioned in specified geometric patterns in the tumour area. The latter allowed a more predictable approach to controlling tumour exposure, even allowing for the primitive state of dosimetry at the time. Joly described the procedure as he and Stevenson deployed it. The radon was collected and sealed in drawn out glass capillaries. These were placed in ordinary hollow exploring needles and held in position by a little paraffin or sealing wax. Using this approach, it was possible to replace a single source of, for example, $200 \mathrm{mg}$ with 20 needles each holding $10 \mathrm{mg}$ and thereby achieve a much more effective and safe dose distribution $[25,26]$.

By 1914 Joly and Stevenson had refined their approach, which came to be known as The Dublin Method, and formed the basis for radium needle treatment of cancer which continued (with further modifications) for over three quarters of a century. The problems of the cost and inadequate supply of radium was assisted through support from the Guinness family and a public appeal for additional funds. At Joly's suggestion, the Royal Dublin Society (RDS) established a 
laboratory to supply radon to hospitals for cancer treatment. He and Stevenson participated in setting up the resulting new Irish Radium Institute, which for many years supplied Irish hospitals with the earliest form of "radium needles". Stevenson's wife died in a drowning accident in 1929, and two years later, at age 54 he succumbed himself due to pneumonia. Joly felt that "no more poignant tragedy had ever touched [him]" than the loss of Stevenson, whom he knew and valued since he was a boy.

This early work in clinical radiation oncology was sustained during the first half of the twentieth century mainly through the radiation oncology services at St Anne's Hospital in Dublin. Later, the work of the Radium Institute moved to St Luke's Hospital. Eventually, radium was replaced by more suitable radionuclides in the form of needles, tubes seeds and wires, and modern brachytherapy began to take shape.

\subsection{Medical Physicist: Edith Stoney, first female medical Physicist} (1859-1938)

Irish physicists will be familiar with George Johnstone Stoney, the former Galway Professor of Physics who coined the term electron. His daughter, Edith, was born in Dublin in 1869, to a family steeped in science and engineering (Fig. 5). Her extended family included George Francis FitzGerald remembered for the Fitzgerald-Lorentz transformation, and was connected with the Parsons (Earls of Ross) noted for encouraging women in science and engineering.

Edith gained a scholarship at Newnham College, Cambridge, where she achieved a First in the Part I Mathematics Tripos examination in 1893. However, she was not awarded a degree as women were excluded from graduation until 1948. She was later awarded a BA and a MA at Trinity College Dublin, after they accepted graduation of women in 1904. She initially took a mathematics teaching post in Cheltenham Ladies' College, and after three years was appointed physics lecturer at the London (Royal Free) School of Medicine [3,27,28].

\subsubsection{London (Royal Free) School of medicine for women}

Edith's sister, Florence, studied medicine at the London (Royal Free) School. She graduated in 1895, obtained her MD in 1898, while Edith

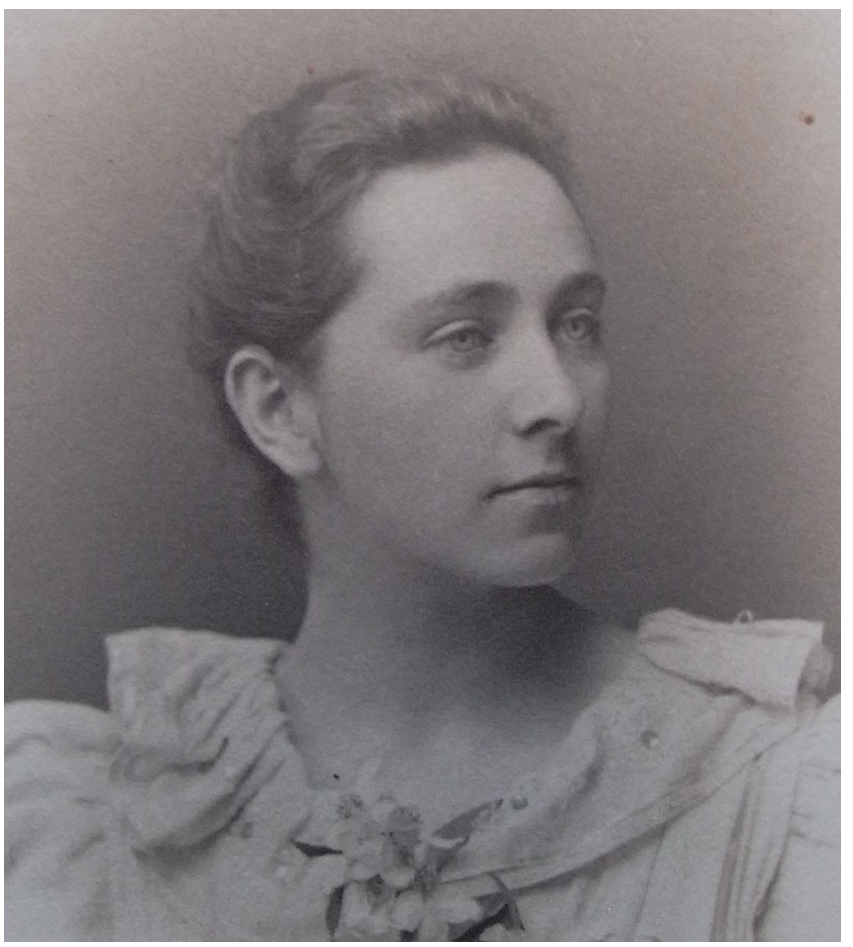

Fig. 5. Photo of Edith Stoney (1859-1938), the first female Medical Physicist. took up her appointment there in 1899. Her first tasks were to set up a physics laboratory and design the physics course. The Royal Free appointed Florence medical electrician in 1901 (the term radiologist did not yet exist), and the following April, the sisters opened a new x-ray service. During their time at the Royal Free Hospital, they actively supported the women's suffrage movement. Edith also played a central role in the British Federation of University Women. [29]

\subsubsection{Involvement in the first world war}

Women made enormous contributions during the First World War. For Edith, this meant taking physics applied to medicine to the front line. She and her sister offered to provide radiological services on the day war was declared, but their offer was refused as they were women. Florence set up her own unit with the Women's Imperial Service League. Edith organised supplies from London where she also served on the League's committee. She resigned from the Medical School and took on the task of planning and operating the X-ray facilities for a 250 bed tented hospital in France. She established stereoscopy to localise bullets and shrapnel and introduced the use of x-rays in the diagnosis of gas gangrene, which proved to be an important marker for immediate amputation. She had to retreat several times, and also established facilities in Serbia and Greece.

Here is an impression of Edith during this period: A learned scientist, no longer young, a mere wraith of a woman, but her physical endurance seemed to be infinite; she could carry heavy loads of equipment, repair electric wires sitting astride ridge tents in a howling gale, and work tirelessly on an almost starvation diet. And another: Grey hair, pale blue eyes, very intent on her job, - no special friend - no other interests, in and out of the $x$ ray rooms and developing rooms like a moth. She received many awards from the UK, France and Serbia.

\subsubsection{Post War, retirement and legacy}

On return to England, Edith took a lecturing post at King's College for Women, which she held until retirement to Bournemouth in 1925. She loved adventure and travelled widely, including to Australia. Newspaper reports from the time described her walking with a stick "with her silvery hair and kind blue eyes, she looks as if she might have engaged all her life in studying Celtic literature": "Small and slight almost to the point of fragility, she names running a motor car, bicycling, and gardening as her favourite hobbies".

She died, aged 69 on 25 June 1938. Her life included opening scientific and professional opportunities to women, and she left two funds to maintain this work. Not long after her death, in 1943, the Hospital Physicists' Association was founded and only 4 out of 53 founder members were women. She would probably be pleased to note a 2015 survey establishing that, now, over $60 \%$ of Irish medical physicists are women (well above the European average of 36\%) [29-31]. She was tough and single-minded with great academic ability, demonstrated bravery and resourcefulness in the face of extreme danger, and imagination in applying physics to clinical care under the most difficult conditions. Her obituaries appeared in a range of publications that few medical physicists reach, including Nature and The Lancet as well as the Times of London, and the Australian Press [32-35].

\subsection{Physicist contributing to Medicine: Erwin Schrödinger (1887-1961)}

Erwin Schrödinger, of Austrian extraction, was one of the most prominent physicists of the 1920 to 1960 period (Fig. 6). Perhaps not widely known is the fact that he worked in Ireland over a long period, having had to flee Austria, in the late 1930's during the Nazi regime. The then Taoiseach (Prime Minister of Ireland), Eamon de Valera, had a lifelong fascination with mathematics and invited him to join the newly formed Dublin Institute for Advanced Studies (DIAS). From then until the mid-50's he lived in Dublin and declared the years he spent there were the happiest of his life. His private life was, to say the least, colourful but his contemporaries, even in a then conservative Ireland, 


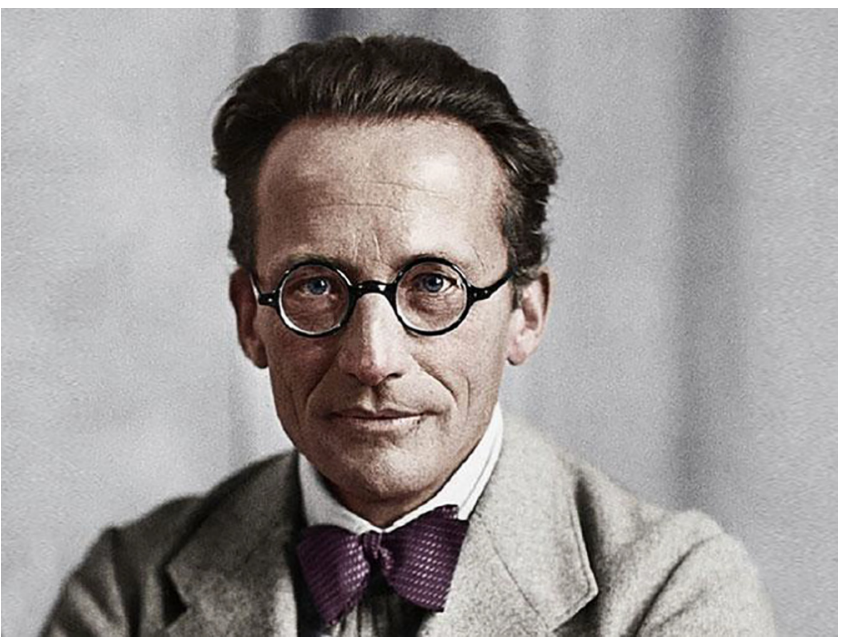

Fig. 6. Erwin Schrodinger (1887-1961).

found it easy to indulge him. One observed that: His private life seemed strange to bourgeois people like ourselves. But all this does not matter. He was a most lovable person, independent, amusing, temperamental, kind and generous... [36-38].

Schrödinger is credited with laying important groundwork for the currently topical human genome project, in a series of public lectures, entitled "What is Life?" delivered in Trinity College Dublin, in 1943. The mechanism for heredity was a critical unsolved question at the time. Since then, molecular biology and molecular medicine have moved centre stage and have improved our understanding of many aspects of medicine and life, including the mechanisms of heredity, human reproduction, cloning, ageing, the origins of life, the basis for consciousness, and numerous contributions to diagnosis and treatments.

From theoretical calculations, Schrödinger was able to confidently conclude that "it is no longer inconceivable that" a miniature molecular code could provide a plausible basis for a highly complicated plan for the development of life. Equally rigorously he noted, drawing on thermodynamics, that, [A living organism] ... feeds upon negative entropy ... Thus the device by which an organism maintains itself stationary at a fairly high level of orderliness (that is, a fairly low level of entropy) really consists in continually sucking orderliness from its environment.

He concluded that, "From all we have learnt about the structure of living matter, we must be prepared to find it working in a manner that cannot be reduced to the ordinary laws of physics. And that not on the ground that there is any "new force"... directing the behaviour of the single atoms within a living organism, but because the construction is different from anything we have yet tested in the physical laboratory".

A book of the lectures was published under the same title What is Life? and had a significant influence on the development of molecular biology. Both James Watson, and independently Francis Crick, credited Schrödinger with presenting an early theoretical description of how the storage of genetic information would work and acknowledged his book as a source of inspiration for their research. Press reports, including Time Magazine, noted the events, but failed to capture the importance of the scientific content.

In terms of the importance of interdisciplinary work, Schrödinger wrote: We feel clearly that we are only now beginning to acquire reliable material for welding together the sum total of all that is known into a whole; but, on the other hand, it has become next to impossible for a single mind fully to command more than a small specialised portion of it... I can see no other escape from (this) - (lest our true aim be lost forever) than that some of us should venture to embark on a synthesis of facts and theories, albeit with second-hand and incomplete knowledge of some of them - and at the risk of making fools of ourselves. Perhaps the sentiment resonates for medical physicists and is one we can relate to.

5.4. St Luke's. related Hospitals, and initial hospital-based medical physics appointments (1950-1970)

Radiotherapy shaped much of the early development of hospital based medical physics in many countries. Ireland was no exception and, once the independent state was declared in 1921, investment in public and centralised health including radiotherapy services was low. Hospital development was in the hands of religious and charitable trusts without strong overarching co-ordination. This was reflected in an exuberant adoption of radiotherapy without a corresponding infrastructure. For example, in Dublin radiotherapy was conducted at the Skin and Cancer Hospital; Dr Steeven's; Hume Street; The Coombe; St Anne's; The Royal City of Dublin; Sir Patrick Dunne's; and The Richmond Hospitals. Most of these had little or no physics support, with the exception of that provided by Joly at Dr Steeven's. Later, some advice was provided by Trinity College's Professor ETS Walton (Nobel Laureate) to Royal City of Dublin department until its closure $[23,25,26,39]$.

In the early 1950s, the Minister for Health took action to provide an efficient, co-ordinated National Cancer Service. A new purpose-built radiotherapy hospital: St. Luke's followed in Dublin. Its first physicist (Dr JE O'Connor) also became head of department and was appointed in 1953. This inaugurated a productive period for Medical Physics in Ireland with a small growing department undertaking interesting and innovative work. Early recruits included Dr Fearghus O'Foghludha (Section 6.3 below) who, regrettably, later departed (Fig. 7). This loss was a harbinger for the subsequent unsatisfactory development of the new service.

Nevertheless, Dr O'Connor assembled a small team, and they served the hospital through the late 50 's up to the mid 90 's. In the earlier part of the period they had a research output, and he developed a "density scaling theorem" which carries his name. An associated centre, St Agatha's in Cork, was also developed, while most other centres

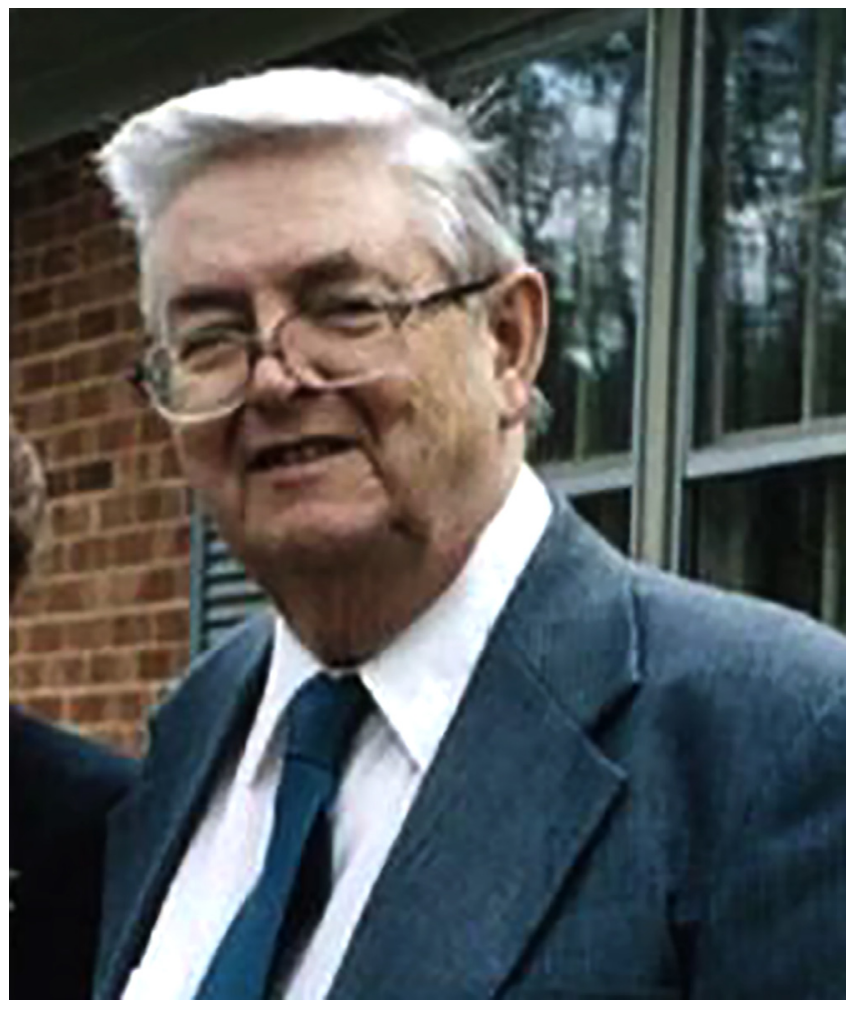

Fig. 7. Fearghus O’Foghludha (1927-2012). 
gradually faded away except St Anne's, which survived until the late 80's and was then merged with St Luke's [40-42].

From the mid-1960s to the late 1990s investment in radiation oncology was limited and services fell behind the international standards that might be expected. The hospital and the medical physics service reflected these difficulties and, to some extent, retreated into a retrenchment/survival mode. However, some progress occurred, and medical physicists were recognised as a distinct profession by the Department of Health in the late 1960s, but development of satisfactory salary scales came much later. By 1970, approximately ten physicists were employed in hospitals throughout the country, most in the radiotherapy hospitals in Cork and Dublin. The increased use of radiation in the health service and elsewhere, saw the initiation of a national personal dosimetry and general radiation monitoring facility, which was also situated at St Luke's (Section 6.1.2).

Over and above the financial constraints of the times, many difficulties at board level in St Luke's spilled over into and undermined the service. These problems continued until the mid-1990's and are further discussed in Section 6 which immediately follows (Section 6.1.1). Some of these are noted in a later (board commissioned) history of the hospital $\boldsymbol{A}$ Haven in Rathgar [42]. It records the story and wounded pride of an institution that was dealt an impossible hand and, unsurprisingly, failed to deliver. The problems were manifold and include persistent failures of communication and respect between the board of the hospital and the civil/public servants of the new state.

\section{Growth and development (1970- 1994/2000)}

This 25/30-year period saw enormous growth of the profession in Ireland, which reflected broader developments in public services and society as the economy grew. The background included new legislation, standards, education and training systems, professional bodies, grading structures and salaries for the profession. These topics are only lightly touched on here and are more fully addressed in Part 2. The grading structure and related salary scales were of fundamental importance. The arrangements established in St Luke's were unsatisfactory and the problems involved could not have been resolved without active participation of a trade union and its senior officials, Phil Flynn and Christina Carney, to whom an exceptional debt is due. They established parity for the profession in Ireland with the main scientific grades in the public service, and thereby physicists became and remain the best paid group of allied health professionals [40]. Significant core medical physics contributions arose in the education sector; Matt Hussey's work on ultrasound is a noteworthy example.

Limited improvements occurred in radiotherapy, but for practical purposes it stalled and did not begin to be reenergised until the end of the century approached (Section 6.1.1). The National Radiation Monitoring Service (NRMS), which had been part of St Luke's Hospital, was moved to the radiation regulatory agency (Section 6.1.2). However, in contrast to the St Luke's situation, rapid development of medical physics occurred in some general hospitals (Section 6.2). Finally, the exceptional career of an Irish Medical Physicist, Fearghus O'Foghludha, is briefly recounted (Section 6.3).

\subsection{St Luke's medical physics and related services (1970_ 1994)}

\subsubsection{St Luke's and medical physics in radiotherapy}

A government commissioned report states: "clinical radiation oncology services were under-developed for the period between the early 1960 s and the 1990s." In addition: "Radiation oncology services, heavily dependent on strategic investment, fell significantly behind the existing international standards of care available at this time." Thus, during the 1980s and early 1990s, the ability to deliver complex treatment protocols was limited. Notwithstanding, the first high energy teletherapy units were installed in St. Luke's Hospital in Dublin and Cork University Hospital during this period [43].
In 1988 St Luke's was formally amalgamated with St Anne's Hospital under a single Board of Management. However, the period from 1988 to 1995 was one during which Medical Physics in both hospitals reached a low point. This was in part due to the unsatisfactory contextual circumstances in both hospitals and unsatisfactory planning and execution of the arrangements to replace John O'Connor, the Chief Physicist, who had retired. Following temporary arrangements, Padraig Coughlan, who had overseen the St Anne's department, was appointed, but in the face of difficult circumstances he retired [41-43].

Repeated failures of imagination, vision, and governance precipitated a crisis of confidence in the depleted medical physics service and Professor Jim Malone (Section 6.2) was asked by the Department of Health to assist the hospital's board and CEO in assessing the situation, and determining if it was safe to continue its operation. There was significant unease about the adequacy of the number of physics staff, the roles and responsibilities assigned to them, and the governance arrangements for the service. The unease coincided with a time when the hospital's licence from the Radiological Protection Institute of Ireland (RPII) was scheduled for renewal. Formal inspections gave serious cause for concern and a worry that the hospital might have to be closed. However, with determined action and major interventions, it was possible to get the service back on track.

The interventions included regular inspections at short intervals by the regulatory authority, who appointed inspectors from outside the state (including Professor Pat Horton) to ensure progress was being made. They also included appointment of a new Chief Physicist (Dr Brendan McClean); arrangements for new facilities, equipment and additional staff; and limitations to the types of work the hospital could undertake pending inspection and licencing of improved arrangements, and so on. All of this was agreed by early 1995. Prof Malone retains a copy of a letter from the board of St Luke's to the CEO of St James's thanking him for helping stabilise the situation. Ironically, shortly thereafter, he also received a summons from the courts to answer charges in connection with a prosecution for inadequate control of radiation of sources at St Luke's/ St Anne's.

Thereafter, during the late 1990's the situation improved greatly with the appointment of a new Chief Physicist and improved governance arrangements, although there was still a long way to go. Public investment significantly enhanced the situation at St Luke's and Cork University Hospital with major associated developments in equipment and staffing. However, by then confidence in the public provision of radiotherapy services had eroded considerably. In consequence, there was a strong commitment to planning and development private radiotherapy services as well as high tech private hospitals that are a feature of the next phase in the development of the history of medical physics in Ireland (see Part 2). The appearance of Radiotherapy and Imaging Centres in the private sector impacted significantly on overall physics staffing during the last three decades.

St Luke's Hospital had little effective academic affiliation throughout this period, although it proved possible to recreate academic links, partly due to moves by the Head of the School of Radiation Therapy to transfer it from St Luke's to Trinity College. Around this time, Donal Hollywood was appointed to the Marie Curie Chair of Clinical Oncology and filled it with distinction. He later delivered the report to government which, among other matters, dealt maturely with medical physicists in radiotherapy, and will be further discussed in Part 2 [43].

\subsubsection{National radiation monitoring service ( 1996$)$}

The increased use of radiation in the health service, among industrial users, and elsewhere saw the development of the first national personal dosimetry and radiation monitoring facility located at St Luke's Hospital. This was named The National Radiation Monitoring Service (NRMS) in 1963, and it gradually acquired a role in environmental monitoring, particularly with regard to nuclear waste disposal and spillage into the Irish Sea from installations in the UK. In 1975 
David Murnaghan was appointed to direct and lead the service's increasing responsibilities. The context for these developments included Ireland's joining the EEC, and significant regulatory developments. The Nuclear Energy Board (NEB) was established in 1977 and absorbed/ relocated the NRMS in due course. The NEB was replaced by the Radiological Protection Institute of Ireland (RPII) in 1992, which had a profound influence on radiation protection in medicine, and eventually became the Office of Radiological Protection in the Environmental Protection Agency (EPA) [40-43].

The NRMS conducted seminal studies of diagnostic imaging. These are often neglected in contemporary reports, but they are part of the heritage and should not be overlooked. The findings are summarised by Murnaghan and others, and in most cases the original studies can be accessed $[44,45]$.

\subsection{Medical physics in the general hospitals (1970- 1994/2000)}

The rapid advance in imaging technology in the early 1970's including, nuclear medicine and CT scanning, led to physicists being appointed to some general hospitals in Dublin. The first of these was in St Vincent's where a physics appointment in support of nuclear medicine was made. This was followed rapidly by three appointments in the Meath, St James's, and Mater Hospitals. While the Meath Hospital and St James's appointments were also primarily for nuclear medicine, they had a broader brief. They were structured differently and made through a Federation of Dublin Voluntary Hospitals (FDVH), which was created to bring a group of hospitals together, assist them develop common services, and prepare them for the troublesome business of integration. It already had a small clinical engineering department. Making the physics appointments in this context created opportunities. Starting from a report prepared in 1976 by Jim Malone the FDVH/St James's group established a physics and engineering service. Malone, an NUIG graduate, was trained in radiotherapy and radionuclide physics at the Department of Medical Physics and Bioengineering, Glasgow which, at the time, was the largest Medical Physics organisation in the world.

The new FDVH/St James's service was formally established as a Department of Medical Physics and Bioengineering in 1983 with a direct reporting relationship to the CEO, a central premises and several satellite units throughout the hospitals. The appointment of a full-time head was delayed because of a dispute between the hospitals and the Department of Health on the grading of the post and freedom of the holder to hold an academic appointment in Trinity College. Both issues were settled in favour of the hospital and, following public competition, Jim Malone was appointed Chief Physicist and Head of the Department. The Bioengineering dimension was initially led by Charles O'Neill, Chief Technologist, whose position was filled, on his retirement by Francis (Fran) Hegarty. "Fran" and Jim Malone worked together for almost 20 years in a concerted effort to deliver the benefits from developments in physics and engineering to the frontline of medicine. The department thrived enjoying a favourable combination of professional leadership, academic opportunity, openness to development, and creative management by senior staff of FDVH (Patrick Corcorane and Tim Lyne) as well as successive CEO's of St James's (John O'Brien and Liam Dunbar) [40,46-49].

Throughout the 80's and 90's growth in the Department continued, diversified and supplied numerous new services to the new University Hospitals being developed at St James's and Tallaght. It became a key player, contributing in a major way to equipping and operational policies, and enjoyed the confidence of both managements and clinicians in disciplines as varied as Cardiology, Medicine for the Elderly, and the Blood Bank. By the mid 90's it had about 40 staff and was organised using a flat management structure with about six working groups including, for example, Diagnostic Imaging; and Endoscopy and Optical Instruments. Cross group membership was important in training and fostering creativity. It also led to development of an exceptional skill set in design and equipping of new facilities. About one third of the work of the department was research or innovation.

An External Services Group emerged from occasional assignments undertaken for other hospitals and agencies throughout the country from the end of the 1970's onwards. At one time, the department was providing RPA services to 6 of the country's 8 Health boards. Through this activity new departments in Waterford, Limerick, Galway were eventually initiated.

During the period of formation and development of the new department, it became painfully obvious that an education and training programme was essential. There was no pool of experienced persons to recruit from, and each recruit absorbed much time in one-to one training. The head of department prevailed on the School of Medicine Deans of the day, Professors Dermot O'B Hourihane and John Bonner to establish a part time MSc programme in Physical Sciences in Medicine. The first intake was in 1981 and the programme lasted, with updates, for over 30 years. Formal in-service training of new recruits was also initiated, largely funded through creative management of the department's resources. Over 150 new entrants to the profession started through these programmes. Jim Malone was appointed Professor in the early 90's, Director of Graduate Studies in 1994, Robert Boyle Professor in 1997/8, and Dean of the School of Medicine and Faculty of Health Sciences in 1999 [13,50]. While these appointments enhanced the profile of Medical Physics, they gradually reduced his contribution to management of the department.

By 1995, only St James's and St Luke's Hospitals had 10 physics employees or more. However thereafter the rapid development to be described in Part 2 took off. Some smaller departments were already established, and others were being set up, typically with between 3 and 5 staff each. The first group in this new wave were the Mater Hospital (Dublin), St. Vincent's Hospital (Dublin), Beaumont Hospital (Dublin), Waterford Regional Hospital (Waterford), the University Hospitals in Galway and Cork. and an innovative national breast cancer screening programme in Ireland called Breastcheck. Both St James's and Galway had good academic links, which they fostered and sustained, and this helped accelerate their development into the new century. The leaders of the new departments were generally trained in Ireland or the UK. Their story carried forward into the contemporary period, will include details of major developments in the private sector that energised renewal in the profession. From a governance perspective, smaller medical physics units are typically part of clinical departments and report to medical directors of radiotherapy and/or radiology.

The service workload of medical physicists, particularly in smaller departments, renders participation in research difficult. Nevertheless, most departments see it as part of their remit. During this period the most successful research group was that in St. James' Hospital which, for over 30 years, participated in or co-ordinated a multitude of large European projects such as DIMOND and SENTINEL. By the mid 80's this group had produced an inhouse digital angiography system like systems being produced in the US at the time [51,52]. Research efforts in other universities and clinical departments are now increasing, but Medical Physics remains a Cinderella in Irish academia, although there are notable exceptions in both research and innovation, which are more fully addressed in Part 2.

\subsection{Medical Physicist: Fearghus O'Foghludha (1927-2012)}

Fearghus O'Foghludha, one of the exceptional medical physicists of the twentieth century, contributed generously to science and the profession on both sides of the Atlantic. He was born and brought up in Dublin. He received a scholarship from the city to attend University College Dublin (UCD) and was awarded BSc, MSc, and PhD degrees in experimental physics. From 1951 to 53, he studied at the Royal University of Uppsala and the University of Lund in Sweden. On returning to Ireland, he served as a Senior Physicist at St. Luke's from 1954 to 1963, following which he moved to the US and had an exceptional career. The US gained and St Luke's lost; had he stayed it is 
just possible that the history of radiation oncology in Ireland might have been different $[53,54]$.

Until 1970, he served in various capacities including Professor at the Medical College of Virginia. He then moved to Duke University, where he was Professor and Director of the Division of Radiation Physics until retirement in 1992. During his career he was President of the American Association of Physics in Medicine (AAPM), editor of Medical Physics, and chaired several of its commissions of the American College of Radiology (ACR). From time to time in his distinguished career, he served as visiting scientist/consultant at Oak Ridge; the National Institutes of Health; the National Science Foundation; the US Atomic Energy Commission, CERN, and the National Aeronautics and Space Administration. He designed an experiment on solar radiation for the Apollo 13 lunar mission and was invited to undertake one of the early investigations into fraud in science. He held several patents, including one granted the year before he died at age 85 .

Fearghus was a good co-worker, a colleague, a mentor, and encouraged one to work with passion for the profession. Meeting him socially or on the side of conferences was always memorable; he was full of good humour with a lively and sometimes outrageous, wit. He loved literature, film, history, language, politics, all things Irish (possibly except St Luke's), and was a good fiddle player. He boasted knowledge of over "1001 useless facts". Many considered him a true "Renaissance man" because of his range of interests, his incisive intellect, and his nuanced use and appreciation of language which made his conversation sparkle. He frequently visited Dublin and took a lively interest in the local developing medical physics scene, to which his advice, if asked, would probably have been: Be authentic to who you are - Play your part - Be grateful for the legacy. Wise words indeed.

\section{The contemporary period ( 1994-2020) and conclusions}

In summary, medical physics and physics in medicine, during the four centuries discussed, are surprisingly healthy over much of the period, given the turbulent nature of Irish history. Specific contributions from figures such as Boyle, Helsham \& Robinson, and Haughton are, though not widely known, significant and memorable. In the twentieth century, Joly's work on radium is an important and little recognised world contribution. Edith Stoney as the first female medical physicist is exceptional and should rank with other important firsts in the profession. Likewise, Schrödinger's groundbreaking work on What is Life found a safe haven in Dublin and is one of the most important physics - medicine interactions of the last century. The initially promising start of radiotherapy physics ran into difficulties, that are being resolved by the present generation and will be reported in Part 2 . The rapid growth of medical physics in some general hospitals and academic centres since the 1970's has been successful, and, as will be seen in Part 2, smoothly transferred to the health system nationwide.

A tantalising preview of this transition is presented in preliminary results of a survey performed with the co-operation of the Irish Association of Physicists in Medicine (IAPM). The country consists of about $75 \%$ of the island of Ireland, intends to continue its membership of the EU, has a population of about 4.9 Million, with a young demographic, and is a relatively wealthy despite, serious disruption during the $2008 / 9$ financial crisis. A total of 228 responses were received with 158 of these holding medical physics positions (i.e. 33 per million of population). Imaging physics staff account for $46 \%$ with the balance in radiotherapy. Of the medical physicists, 104 are qualified MPEs, 29 are certified RPAs, 91\% hold Master's degrees; and 25\% hold PhDs. Thirty one percent (50) received at least part of their training working aboard, thirty-three per cent (52) have professional work experience in other countries, eleven percent (18) are originally non-nationals. This hopefully valuable preview of the data emerging from the survey can only be touched on here. Part 2 will include a more comprehensive account of it.

The findings from this investigation to date provide a rich context and heritage for medical physics and physics in medicine in Ireland, something we are happy to share with the European and wider international communities, some of whom may find it valuable when excavating their own history.

\section{Acknowledgments}

We are grateful to the officers and membership of the IAPM for their support with this project. We also thank the Heads of Department who generously responded to the survey in a timely way. JM is grateful to the Chairman and trustees of the Robert Boyle Foundation for their ongoing support.

\section{References}

[1] Bertocchi L, Benini A, Milano F, Padovani R, Sprawls P, Tabakov S. 50 years ICTP and its activities in the field of medical physics. Med Phys Int 2014;2:410-4.

[2] Laguardiara RA. The development of the medical physics profession in the central Americian Region. Medical Physics International; 2017.

[3] Duck FA. Edith Stone MA, the first woman medical physicist. Scope 2013;22:49-54.

[4] Hunter MCW, Boyle R, Wotton W. Robert Boyle by himself and his friends. London: William Pickering; 1994.

[5] Hunter M. Boyle: Between God and Science. New Haven; London: Yale University Press; 2010.

[6] Malone J. Robert Boyle: a major contributor to European science. J Ir Coll Physicians Surg 1993;22:137-41.

[7] Malone J. Darker sides of Twenty-Frist-Century Science and Perspectives from a Founding Father. In: Sweetman B, editor. Philosophical Thinking and the Religious Context. New York and London: Bloomsbury; 2013. p. 68-79.

[8] Boyle R, Birch T. The works of the Honourable Robert Boyle: in six volumes: to which is prefixed the life of the author: volume the first[-sixth]. London: Printed for W. Johnston, S. Crowder, T. Payne, G. Kearsley, J. Robson, B. White, T. Becket and P.A. De Hondt, T. Davies, T. Cadell, Robinson and Roberts, Richardson and Richardson, J. Knox, W. Woodfall, J. Johnson, and T. Evans; 1772.

[9] Boyle R. Memoirs for the Natural History of Humane Blood. London: Samuel Smith; 1684.

[10] Boyle R. Two essays concerning the unsuccessfulness of experiments. London: Henry Herringham; 1668.

[11] Clarke N, https://nualaclarke.com/SHOW-Experiments-and-ConsiderationsTouching-Colours 24 June 2019.

[12] Coakley D. Irish masters of medicine. Dublin: Town House; 1992.

[13] Coakley D. Medicine in Trinity College Dublin: an illustrated history. Dublin: Trinity College Dublin; 2014.

[14] Helsham R, Weaire D, Kelly P, Attis DA. A course of lectures in natural philosophy. Dublin; Bristol: Physics Department of Trinity College; Institute of Physics Publishing; 1999.

[15] https://en.wikipedia.org/wiki/Richard_Helsham 30 June 2019.

[16] http://www.askaboutireland.ie/reading-room/life-society/science-technology/ irish-scientists/helsham-richard/ 2019 21st June.

[17] http://dr-steevens-hospital-a-history.edwardworthlibrary.ie/Doctors/Robinsonand-Helsham/ 21 June 2019.

[18] https://en.wikipedia.org/wiki/Bryan_Robinson_(physician)) June 302019.

[19] Roche J. A course of lectures in natural philosophy. Eur J Phys 2000;21:275-7. https://doi.org/10.1088/0143-0807/21/3/702.

[20] Mulvihill M, https://ingeniousireland.ie/2012/10/halloween-samuel-haughtonshumane-hanging/ 24 June 2019.

[21] Haughton S. Principles of Animal Mechanics. London: Longmans, Green, and Co; 1873.

[22] Joly John, 1857-1933. Obit Not Fell R Soc 1934:258-86.

[23] Joly J. History of the Irish Radium Institute. In: Carr JC, editor. A Century of Medical Radiation in Ireland: An Anthology. Dublin: The Anniversary Press; 1995. p. 83-92.

[24] https://en.wikipedia.org/wiki/John_Joly June 302019.

[25] Murnaghan DJ. History of Radium Therapy in Ireland and the Irish Radium Institute: The Dublin Method. In: Carr JC, editor. A Century of Medical Radiation in Ireland: An Anthology. Dublin: The Anniversary Press; 1995. p. 227-34.

[26] Walter Coakley D, Stevenson Clegg. Irish Masters of Medicine. Townhouse: Dublin; 1992. p. 263-9.

[27] Duck FA. Physicists and physicians: a history of medical physics from the Renaissance to Röntgen. York: Institute of Physics and Engineering in Medicine; 2013.

[28] https://en.wikipedia.org/wiki/Edith Anne Stoney June 302019.

[29] History of the Hospital Physicists' Association 1943-1983: comp. and ed. London: H. P.A.; 1984.

[30] Tsapaki V, Rehani MM. Female medical physicists: The results of a survey carried out by the International Organization for Medical Physics. Phys Med Eur J Med Phys 2015;31:368-73. https://doi.org/10.1016/j.ejmp.2015.02.009.

[31] Federation of University Women. Executive Committee Minutes 1909-1916 (5BFW/ 02/01). London: The Womens Library Archive (London School of Economics).

[32] Miss Edith Stoney. Nature. 1938;142:103-4, https://doi.org/10.1038/142103b0.

[33] OBITUARY Edith Stoney MA The Lancet. 1938;232:108, https://doi.org/10.1016/ 
S0140-6736(00)78712-5.

[34] Cullis WC. Miss Edith Stoney. The Times1938. pp. 16.

[35] Miss Edith Stoney's aid to science. Brisbane Courier-Mail 30th July 1938. pp. 2.

[36] Moore WJ. Schrödinger, life and thought; 1998.

[37] Gribbin J. Erwin Schrodinger and the Quantum Revolution. Somerset: John Wiley \& Sons; 2013.

[38] Schrodinger E. What is life? Cambridge U.P., 1944.

[39] Carr JC, Babel H, Royal College of Surgeons in I, Faculty of R. A Century of Medical Radiation in Ireland: an anthology. [Dublin]: Anniversary Press; 1995.

[40] Van der Putten W. Medical Physics in Europe - Ireland. European Medical Physics News; 2009. p. 10-5.

[41] Murnaghan DJ. St. Luke's Hospital. In: Carr JC, editor. A Century of Medical Radiation in Ireland: An Anthology. Dublin: The Anniversary Press; 1995. p. 93-8.

[42] Farmar T. A Haven in Rathgar : St Luke's and the Irish Experience of Cancer 1952-2007. Dublin: A. \& A. Farmar; 2007.

[43] Hollywood D. The Development of Radiation Oncology Services in Ireland. Dublin, Health Services Executive; 2003. Available at: https://www.hse.ie/eng/services/ list/5/cancer/pubs/reports/development-of-radiation-oncology-in-ireland.pdf Accessed Jan 2020.

[44] Murnaghan DJ, Powell MA. Development of X-Ray Protection. In: Carr JC, editor. A Century of Medical Radiation in Ireland: An Anthology. Dublin: The Anniversary Press; 1995. p. 150-5.

[45] Powell MA, Cross F, Egan LJ, McCarthy MD, O'Connor JE, O'Sullivan D. The National Radiation Monitoring Service. Report of the Special Survey of Radiological Departments in Ireland to determine the annual number of radiological examinations performed, the gonad dose delivered by each type of examination and the genetically significant radiation dose contributed to the population by diagnostic radiology. Ir J Med Sci 1970;3:85-101. https://doi.org/10.1007/ bf02955222.

[46] Malone JF, O'Neill C, OC JE. Medical Physics and Bioengineering in the Republic of Ireland. Hospital Physicists Association (HPA, UK). Bulletin 1975:34-9.

[47] Malone JF, O'Neill C. The Contribution of Medical Physics and Engineering to Hospitals in the 1980s. Conference Reprot of the Federated Dublin Voluntary Hospitals (FDVH) and St James's Hospital. FDVH Dublin1980. p. 12-3.

[48] Malone JF. Education and Training for Medical Physics and Bioengineering in the Irish Health Service. Assoc Phys Sci Med Bull 1985:22-5.

[49] Van der Putten W. 'Much Ado About Nothing': on the distinction between medical physics and clinical engineering. Int J Healthcare Technol Manage (IJHTM) 2010;11:429-41. https://doi.org/10.1504/IJHTM.2010.036924.

[50] Coakley D, Coakley M. The history and heritage of St James's Hospital, Dublin. Dublin and Chicago: Four Courts Press; 2018.

[51] Maher K, O'Connor K, Malone JF. Densitometric analysis in digital subtraction angiography. Med Biol Eng Comp 1985;23:1534-5.

[52] Chakraborty DP, Gupta KL, Barnes GT, Vitek JJ. Digital subtraction angiography apparatus. Radiology 1985;157:547. https://doi.org/10.1148/radiology.157.2. 3901116.

[53] O'Donovan N, Hone C, Turvey FJ. Survey of nuclear medicine practice in Ireland. Ir J Med Sci 1988;157:310-5.

[54] Nelson CE. Fearghus O'Foghludha, 1927-2012. Medical Physics. 2012;39:i-i, doi: $10.1118 / 1.4747612$. 